\title{
Early Manuscript Dissemination
}

\author{
Jaakko Tahkokallio
}

Since its release, the De gestis Britonum has been defined by its popularity. The work became successful quickly and the material record of its early reception is exceptional in its extent. The count of surviving manuscripts runs to 225 at the moment, and almost 8 o of them can be dated to before $c .1210 .{ }^{1}$ In what follows I shall examine the first stages of the transmission and reception of the $D G B$ using these early manuscripts as my primary body of evidence.

The first part of this chapter discusses the earliest dissemination of the work, bringing together evidence from the manuscripts, textual transmission, and narrative and documentary sources. I start from the process of how the text was released and move on to discuss the role of the dedicatees and early documented readers in the circulation of the text. I also suggest circumstances in which the three dedications of the work were probably penned and look briefly at the genesis of the textually idiosyncratic versions of the work, the socalled First and Second Variants. This part depends heavily on Michael Reeve's textual work and the division of the transmission of the $D G B$ into two main families, depending on lost archetypes $\Phi$ and $\Delta$ respectively.

In the second part, I turn to what the manuscripts tell us about the early audience and its attitudes toward the $D G B$. Here, I first provide an overview of what is known about the origins of the early copies and point out the scale of early monastic dissemination, in particular on the Continent. Despite its

1 I include manuscripts dated to $s$. xii or $s$. xii/xiii in this count. For descriptions of the manuscripts, see Crick, SC; ead., "Two Newly Located Manuscripts of Geoffrey of Monmouth's Historia regum Britanniae", $A L 13$ (1995), 151-56; and J. Tahkokallio, "Update to the List of Manuscripts of Geoffrey of Monmouth's Historia regum Britanniae", AL 32 (2015), 187-203. After the publication of the latest up-date article, a further early-14th-century copy came to surface at a Christie's sale in London (2015, Sale 1568), and was bought by Trinity College, Dublin (now Dublin, Trinity College, 11500). DGB remained available well into the modern era as well. The first printed editions are from 1508, when Ponticus Virunius published an abbreviated version (Reggio Emilia, 1508; reprinted twice, in Augsburg, 1534, and London, 1585) and Ivo Cavellatus published the complete text (Paris, 1508, reprinted in 1514). Hieronymus Commelinus re-edited the work and published it in 1587 (Heidelberg). The next full edition of the $D G B$ was prepared in London 1844 , and reproduced in 1854 (Halle). $P M$ has been published separately in $1603,1608,1649$ (all three editions with the commentary attributed to Alan of Lille), 1837, 1840 and 1853 . For the editions, see $D G B$, pp. lxii-lxiv.

(C) THE AUTHOR, 2020 | DOI:10.1163/9789004410398_007

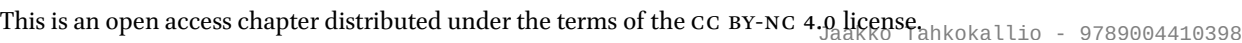


arguably secular and controversial content, the $D G B$ was widely accepted into institutional libraries and copied alongside respectable historical works. However, I also draw attention to the fact that information about origin is available only for a relatively small part of the manuscript corpus. In the final and more speculative part of the chapter I discuss the possibility that a significant share of the 12th-century copies were originally produced for individual readers outside monastic scriptoria. The chapter closes with a detailed examination of some early continental copies which probably have non-institutional origins and in whose making professional or semi-professional artisans may have been involved.

\section{Release and Early Transmission}

The circulation of the $D G B$ started with the release of a prelude. Geoffrey himself wrote in the $D G B$ that rumors about Merlin had started to circulate before he had reached the point in the $D G B$ to which the Prophetiae Merlini belonged. To satisfy the curious, he explained, he had sent the $P M$ to Alexander, bishop of Lincoln (d. 1148), with a cover letter that was included in most versions of the $D G B$ as well. ${ }^{2}$ We have a terminus ante quem for this separate release of the $P M$, thanks to Orderic Vitalis (1075-C.1142), monk of Saint-Evroul (in Normandy). In his Ecclesiastical History, Orderic quoted at length from a booklet which he called Libellus Merlini, "The Little Book of Merlin". He also speculated on what the $P M$ meant to say about Henry I of England whose destiny, according to him, still remained open. This means that Orderic had access to the text before Henry's death which took place in December $1135 .^{3}$

The separate release of the Libellus is well attested in the manuscript record as well. The $P M$ exists in 13 independent copies datable to the 12th century (including manuscripts dated to $c .1200$ ). By comparing their texts to Orderic's lengthy quote from the Libellus Merlini - a certain witness to the independently released version - it has been possible to determine whether manuscripts containing only the $P M$ really stem from the independently released libellus or

2 DGB, vii.109.1-7: "Nondum autem ad hunc locum historiae perueneram cum de Merlino diuulgato rumore compellebant me undique contemporanei mei prophetias ipsius edere, maxime autem Alexander Lincolniensis episcopus ... Cui cum satisfacere praeelegissem, prophetias transtuli et eidem cum huiusmodi litteris direxi."

3 Orderic Vitalis, Ecclesiastical History xii.47 (iv.486), ed. and trans. M. Chibnall, The Ecclesiastical History of Orderic Vitalis, 6 vols., Oxford, 1969-8o, vol. 6, p. 381. On the dating of the passage, see Chibnall, "Introduction", p. xviii. See also Bern, ed. Wright, pp. xii-xvi, and $D G B$, p. viii. 
were extracted from the complete $D G B$ later on. ${ }^{4}$ This comparison shows that while some of the independent $P M$ are indeed extracts from the $D G B$, at least nine of the surviving 12th-century copies descend from the independently released text. ${ }^{5}$

Orderic was by no means exceptional in having early access to the $P M$ on the Continent. In fact, six out of nine of the 12th-century copies belonging to the independent line of transmission are continental. ${ }^{6}$ At the same time, chronicle and charter evidence shows that the patron of the work, Alexander of Lincoln, was in Normandy for a substantial period around the time of its probable presentation to him, starting at some point in 1134 and ending before Easter $1136 .{ }^{7}$ Furthermore, when the preface to Alexander appears as a part of the $D G B$, Geoffrey introduces it with the words eidem cum huiusmodi litteris direxi, for which the most natural translation is "I sent [them] to him with this letter." In the independent $P M$ manuscripts, the letter is at times included and at times not, which could indicate that it was originally a separate document. ${ }^{9}$ The wide early availability of the $P M$ on the continent, combined with what we know about Alexander's movements, suggests the possibility that Geoffrey may have presented the $P M$ to Alexander in Normandy in 1134 or 1135, perhaps by sending it to him with a cover letter.

At the same time, the Insular manuscripts hint that, in Britain at least, Alexander played a role in the early transmission of the work, and that its

4 See $D G B$, pp. xxix-xxxi.

5 Berlin, Staatsbibliothek, theol. lat. quarto 328; Liège, Bibliothèque publique centrale, $369 \mathrm{C}$; Lincoln, Cathedral Library, 214; London, British Library, Additional 25014; Oxford, Lincoln College, Lat. 27; Paris, Bibliothèque nationale de France, lat. 2935, lat. 6237, lat. 6274, lat. 7481, lat. 9422, lat. 14465, lat. 15172; and Vatican City, Biblioteca Apostolica Vaticana, Reg. lat. 807. Of these, BL Add. 25014, BnF lat. 7481, and BNF lat. 9422 are extracts, and the affiliation of Berlin, theol. lat. qu. 328 is unclear.

6 The continental manuscripts are Berlin, theol. lat. qu. 328; BnF lat. 2935, lat. 6237, lat. 6274, lat. 15172; and BAV, Reg. lat. 807. The three Insular copies with the independent text are Liège 369; Lincoln 214; and Oxford, Lincoln College, Lat. 27.

7 Alexander went to King Henry's court in Normandy at some point in 1134 to settle a dispute with the archbishop of Canterbury (Henry of Huntingdon, History of the English vii.43, ed. and trans. D. Greenway, Henry, Archdeacon of Huntingdon: Historia Anglorum. The History of the English People, Oxford, 1996, p. 49o). In September 1134 he witnessed a royal charter at Verneuil (Regesta regum Anglo-Normannorum, 1066-1154, ed. H.W.C. Davis et al., 4 vols., Oxford, 1913-69, vol. 2, no. 1895) and probably around that date King Henry secured Lincoln's privileges, at Arganchy and Rouen, presumably at Alexander's initiative (ibid., vol. 2, nos. 1899 and 1911). Alexander was back in England by Easter 1136 when he witnessed King Stephen's charter in London (ibid., vol. 3, no. 46).

8 Neil Wright's translation, $D G B$, vii.109.7.

9 Of the 12th-century $P M$ manuscripts belonging to the independent transmission, Oxford, Lincoln College, Lat. 27; BnF lat. 2935, lat. 6237, and lat. 15172 exclude the letter. 
circulation may even have been restricted to circles close to him there, while it enjoyed wider success on the Continent. Two of the three 12th-century British copies stemming from the independent release have an association with Lincoln: one belongs to the Lincoln Cathedral Library and the other to Lincoln College, Oxford, to which it came from the Gilbertine house of Sempringham, founded by Alexander. ${ }^{10}$

Alexander was one of the great ecclesiastical princes of the day and also the patron of another contemporary English historian, Henry of Huntingdon (c.1088-c.1157).$^{11}$ However, for the $D G B$ Geoffrey turned to another source of patronage: Robert, earl of Gloucester (d. 1147), Henry I's illegitimate son. Robert was born before the king's marriage and enjoyed a special status among the royal bastards, especially after the death of Henry's only legitimate male heir in 1120. He was highly educated, and not only Geoffrey but also William of Malmesbury dedicated historical works to him..$^{12}$ A possible link between Robert and Geoffrey might have been provided by the scholarly connections between Caen, which was Robert's Norman base, and St George's collegiate church of Oxford, of which Geoffrey was a canon..$^{13}$

Whatever the origin of the connection, the earliest version of the $D G B$ was dedicated to Robert and he no doubt received a copy of it early on. Just as is the case with the $P M$, this presentation may well have taken place in Normandy. William of Malmesbury's The Contemporary History tells us that Robert of Gloucester stayed there from Easter 1137 until September 1139, which is the most likely time window for the work's presentation to him. ${ }^{14}$ Furthermore, the earliest report about the existence of the $D G B$ comes from the Norman

10 Oxford, Lincoln College, Lat. 27 bears a Sempringham ex libris datable to $c .1200$ (fol. 6v) and contains two letters to St Gilbert of Sempringham.

11 D.M. Smith, "Alexander (d. 1148)", Oxford Dictionary of National Biography, Oxford University Press, 2004, <http://www.oxforddnb.com/view/article/324> (accessed 13 March 2017).

12 For Robert's life and career, see D. Crouch, "Robert, earl of Gloucester and the Daughter of Zelophehad", Journal of Medieval History 11:3 (1985), 227-43.

13 See R. Foreville, "L'École de Caen au XI ${ }^{\mathrm{e}}$ siècle et les origines normandes de l'université d'Oxford", in Études médiévales offertes à M. le Doyen Augustin Fliche de l'Institut, Montpellier, 1952, pp. 81-10o. On the canons of St George, see J. Barron, "The Augustinian Canons and the University of Oxford: the Lost College of St George", in C.M. Barron and J. Stratford (eds.), The Church and Learning in Later Medieval Society: Essays in Honour of R.B. Dobson, Donington, 2002, pp. 228-54. For Geoffrey's relationship to the college of St George, see E. Salter, "Geoffrey of Monmouth and Oxford", EHR 34 (1919), 382-85 and M.D. Legge, "Master Geoffrey Arthur", in K. Varty (ed.), An Arthurian Tapestry: Essays in Memory of Lewis Thorpe, Glasgow, 1981, pp. 22-27.

14 For the chronology of Robert's movements, see William of Malmesbury, The Contemporary History, ed. E. King, trans. K.R. Potter, William of Malmesbury. Historia novella: The 
abbey of Le Bec, where Henry of Huntingdon was astonished by finding it in January $1139 \cdot{ }^{15}$ We cannot be sure how long before that the work had been put into circulation, but it seems unlikely that Henry, who belonged to the same intellectual circles as Geoffrey and shared his interests, would have remained unaware of it for long afterwards. A presentation of the work taking place in Normandy in $1137-38$, or alternatively immediately before Robert's departure from England at Easter 1137, would be very much compatible with Henry's surprise, and, while this scenario remains unproven, it also fits together with the early textual transmission of the work, to which I will come back shortly.

At Le Bec, Henry of Huntingdon was introduced to the $D G B$ by the prior of the house, Robert of Torigni (c.1110-86), a well-known chronicler in his own right. He is also the first person in the history of the dissemination of the $D G B$ with whom we can associate a surviving manuscript. This is the earliest relatively securely dated copy of the $D G B$, now kept in Leiden, which was produced at Le Bec under Robert's supervision. ${ }^{16}$ This manuscript contains several historical works, including Robert of Torigni's redaction of The Deeds of the Norman Dukes, and it was copied in two stages. The first one, penned in the 113os, included The Deeds of the Norman Dukes, Einhard's Life of Charlemagne, Alexander material, and two brief chronicles. Sometime around 1150, the $D G B$ and the Historia Brittonum were added.

On the account of its textual features, the first half of the Le Bec copy of the $D G B$ descends from a manuscript now kept at Bibliothèque Sainte-Geneviève

Contemporary History $\S 466$ and $\S 478$, Oxford, 1998, pp. 21-22 and 34. See also Crouch, "Robert, earl of Gloucester", p. 232.

15 Henry was on his way to Rome with Theobald, archbishop of Canterbury. The story is reported by Henry in his Letter to Warin, reproduced in Henry of Huntingdon, History of the English, ed. and trans. Greenway, pp. 558-83.

16 Leiden, Universiteitsbibliotheek, B.P.L. 20 (number 76 in Crick's Summary Catalogue; from here on, I provide references to Crick's Summary Catalogue in the form " $D G B \mathrm{~ms} 76$ "). For Robert's role at the library of Le Bec, see D. Bates, "Robert of Torigni and the Historia Anglorum", in D. Roffe (ed.), The English and Their Legacy, 900-1200. Essays in Honour of Ann Williams, Woodbridge, 2012, pp. 175-84. Robert's involvement in the production of the Leiden manuscript been suspected for long and confirmed by Benjamin Pohl's recent work; see B. Pohl, "Abbas qui et scriptor? The Handwriting of Robert of Torigni and his Scribal Activity as Abbot of Mont-Saint-Michel (1154-1186)", Traditio 69 (2014), 45-86. As Pohl explains, Robert did not copy any of the works himself, but the manuscript was corrected and annotated with nota monograms by him. Pohl's article does not discuss the monograms, but they are in the same hue of ink as the textual notes which Pohl identifies as being in Robert's hand. They are also very similar to the nota monograms seen in two copies of Henry of Huntingdon's History of the English associated with Robert: Paris, Bibliothèque nationale de France, lat. 6042, and Cambridge, University Library, Gg.2.21. For the ownership history of BnF lat. 6o42, see Pohl, “Abbas qui et scriptor?”, p. 67. 
(henceforth, G) ${ }^{17}$ This manuscript is in fact the starting point of all of the early continental circulation and altogether 70 manuscripts depend on it textually. While G may not, on the first look, give the impression of being paleographically quite so early, its position in the continental stemma is beyond doubt because of textual evidence. Its scribe first omitted some words in copying it, and then added them as corrections - but some of them in wrong places. This odd misplacement is seen in virtually all continental copies from before the last quarter of the 12th century, including the Leiden manuscript. ${ }^{18}$

Curiously, however, these continental copies repeat the mistakes of $G$ only for its first half, until $D G B \S 108$. After this point, they start following directly the exemplar of G, which was a lost copy of the archetype $\Phi .{ }^{19}$ To account for such a textual situation, we must assume that there existed a copy which descended partly from $\mathrm{G}$ and partly from its exemplar. This copy, which we may call post$G$, then gave birth to a large number of further copies.

One wonders, of course, why post-G was copied partly from $G$ if its exemplar, a copy with more textual authority, was also available. The structure of $G$ suggests an answer. The point at which post- $G$ stopped following $G$ and reverted directly to its exemplar (§108) coincides with a change of scribal hand in G. This takes place very near the end of the fourth quire, six lines from the bottom of its last verso side. My suggestion is that once the first four quires of $G$ were finished, they were immediately put into use as an exemplar for another copy, while the copying of the rest of $G$ was still taking place from the original exemplar. Once the copying of post-G arrived at $\S 108$, G itself was complete and its original exemplar had become available. Preferring it to $G$ would have been an obvious choice, especially since the second half of $\mathrm{G}$, copied by another scribe, is less careful work than the first four quires.

17 Paris, Bibliothèque Sainte-Geneviève, 2113 ( $D G B$ ms 191).

18 See M.D. Reeve, "The Transmission of the Historia regum Britanniae", Journal of Medieval Latin 1 (1991), 73-117, at p. 84, and also $D G B$, p. xv. The distinctive transpositions occur at $D G B$ §6.55 (Cumque id |patri| Ascanio), §8.97-98 (celsitudinem |tue| potentiae), §76.94 (habere captaret |de illo| uenerunt uenedoti), §81.212 (mauricus magnae |et pulchre| staturae), §95.185 (melius potestati |sue| et familiaritati), and §106.523-24 (in ecclesia sancti petri |in eadem urbe| inter monachas). However, for their second half the continental manuscripts follow the exemplar of the Sainte-Geneviève manuscript directly, not repeating its errors. The only continental manuscripts from before the last quarter of the century which have a different progeny are Alençon, Bibliothèque municipale, 12 ( $D G B$ ms 12) and Paris, Bibliothèque nationale de France, lat. 6232 (DGB ms 177), partly following the Sainte-Geneviève manuscript but partly copied from an Insular exemplar.

19 See $D G B$, pp. xiv-xv. London, British Library, Additional 15732 (s. xii, continental) is the only 12 th-century manuscript descending directly from $\mathrm{G}$ in its entirety. 
We know from Henry of Huntingdon's testimony that Robert of Torigni possessed a copy of the $D G B$ in 1139, and that the Leiden manuscript was later copied under his supervision from post- $G$ (or its descendant). Given that $G$ was copied at the very beginning of the continental transmission, it may well be a result of scribal activity taking place around Robert of Torigni. Paleographically, the Sainte-Geneviève manuscript appears quite certainly Norman and indeed is not far away from manuscripts that can be associated with Robert himself. ${ }^{20}$ Neil Wright has suggested that $G$ itself could have been Robert's personal copy, and this is certainly a possibility. ${ }^{21}$ However, since Robert is known to have had an active role in the circulation of texts in Normandy, perhaps an even more likely candidate for his personal copy might be post-G, i.e., the lost manuscript descending partly from $G$. It was post-G (or its descendant), after all, which he later made the Le Bec scribes use as their exemplar and which was also widely copied by others.

What we know about Robert of Gloucester's later movements and the textual history of the $D G B$ is compatible with the hypothesis that the work was released into wider circulation by presenting it to him in Normandy (or in England immediately before his departure in 1137). The whole of the early continental transmission descends from the lost archetype $\Phi$, via $G$ and post- $G$, as argued above. The descendants of $\Phi$ show greater consistency in their chapter markings, rubrics, and initials than manuscripts of other textual branches. Michael Reeve has plausibly suggested that $\Phi$ was the presentation copy given to Robert, since in such a copy attention would have been given to these final touches. ${ }^{22}$

In Britain, the majority of the early manuscripts descend from another archetype, the so-called $\Delta$, and overall the textual division between the Continent and Britain is surprisingly sharp. The Channel appears, in this case, to have been more of a barrier than a conduit for the circulation of texts. However, while $\Delta$ has no early continental witnesses, $\Phi$ has some textually significant descendants that are clearly of British origin. Interestingly, circumstantial evidence suggests a connection to Robert of Gloucester for many Insular copies depending on $\Phi$.

$20 \quad$ For manuscripts produced close to Robert, see in particular Pohl, "Abbas qui et scriptor?".

21 N. Wright, “The Place of Henry of Huntingdon's Epistola ad Warinum in the Text-History of Geoffrey of Monmouth's Historia regum Britanniae: a Preliminary Investigation", in G. Jondorf and D.N. Dumville (eds.), France and the British Isles in the Middle Ages and Renaissance: Essays by Members of Girton College, Cambridge, in Memory of Ruth Morgan, Woodbridge, 1991, 71-113, at p. 89 .

$D G B$ p. lx, and Reeve, “Transmission”, p. 102, n. 5 . 
London, British Library, Royal 13 D. ii ( $D G B$ ms 112) is textually the most important of these manuscripts. It was by the 13th century (at latest) at Margam Abbey (Cistercian, Glamorgan), which was Robert of Gloucester's foundation, possibly founded at his deathbed. Furthermore, the manuscript also contains excellent textual witnesses - all copied by the same scribe - of other texts dedicated to Robert of Gloucester, i.e., William of Malmesbury's Deeds of the English Kings and The Contemporary History, the latter of which is largely a story about Robert himself. Finally, in the Margam manuscript, The Contemporary History has rubrication that is not found in any other copy and that casts Robert's character and actions in very favorable light.

Throughout, the textual quality of these works is remarkable. As regards William's Deeds of the English Kings, the Margam text has enjoyed a privileged position in its editorial history. ${ }^{23}$ For the $D G B$, the Margam text is the best representative of the principally continental $\Phi$ family - and also, arguably, the best single witness to the text of the $D G B$ overall. In Michael Reeve's words, "a transcript of M [=Margam Abbey ms] would be a tolerable substitute for an edition." ${ }^{24}$ Indeed, the editor of The Contemporary History has suggested that the compilation of texts and the rubrics were created by Robert's son, Roger, bishop of Worcester $(c .1134-79) .{ }^{25}$ The Margam copy is from the very end of the 12th or the beginning of the 13th century and thus it postdates both Robert and his son Roger. However, one is bound to wonder whether the scribe who copied it used as his exemplar for the $D G B$ the manuscript which Robert of Gloucester had been given, probably in Normandy (and from which the continental transmission had started), and which he brought to England and eventually left to his son Roger.

Robert certainly had a copy of the $D G B$ in his possession after he returned to England in September 1139, since Gaimar's Estoire des Engleis tells us that he provided the text to Walter Espec, a Yorkshire magnate, most likely in the early 1140s. ${ }^{26}$ This loan, so it would seem, initiated another English branch

23 R.M. Thomson and M. Winterbottom, "Introduction", in William of Malmesbury, Deeds of the English Kings, ed. and trans. R.A.B. Mynors, completed by R.M. Thomson and M. Winterbottom, William of Malmesbury: Gesta Regum Anglorum, The History of the English Kings, 2 vols., Oxford, 1998-99, vol. 1, pp. xiii-xxviii, at pp. xviii-xix.

$24 \quad D G B$, p. xvi.

25 For the "Robertian" nature of the text of The Contemporary History, see E. King, "Introduction", in William of Malmesbury, The Contemporary History, ed. King, pp. lxxviixciv. For the possible connection with Roger of Worcester in particular, see ibid., pp. xci-xciv.

26 The precise date of Gaimar's Estoire remains open. I. Short, "Gaimar's Epilogue and Geoffrey of Monmouth's Liber vetustissimus", Speculum 69:2 (1994), 323-43, has argued for an early date, in the 113os, while P. Dalton, "The Date of Geoffrey Gaimar's Estoire des 
of transmission depending on the archetype $\Phi$. The key manuscript of this group is Cambridge, Gonville and Caius College, 406/627 (DGB ms 30), which likewise has substantial textual authority and served as one of the five manuscripts Reeve used for reconstructing archetype $\Phi$. This 12th-century manuscript was kept by $c .1300$ at Bridlington Priory (Augustinian, Yorkshire) and its 12th-century marginalia suggest that the manuscript was already in Yorkshire in the 12th century. ${ }^{27}$ Bridlington Priory belonged to the Yorkshire network of Augustinian houses, in which Walter Espec took interest. ${ }^{28}$

What is more, its decoration merits attention. The manuscript, which contains only the $D G B$, opens with two multi-color initials, one of which shows a long-haired character wearing a crown-like headgear (in the upper lobe of a "B"), and a grumpy-looking clerk (in the lower lobe). The most obvious idea would be to interpret these characters as a patron and an author, but the patron, portrayed with long blond hair, may well be female, unlike the dedicatees of the text. According to Gaimar, Walter Espec provided the $D G B$ to Ralf fitz Gilbert, and it was his wife, Lady Constance, who was Gaimar's patron. Gaimar also tells us that he himself made a copy of this manuscript. One wonders whether the persons portrayed could even be Lady Constance and Gaimar, and whether this could have been the copy which Gaimar made, although paleographically the manuscript seems too late for this. ${ }^{29}$ Whomever the figures represent, they are exceptional in the transmission of the $D G B$ and do not seem to reflect any known tradition of decoration.

Engleis, the Connections of his Patrons, and the Politics of Stephen's Reign", The Chaucer Review 42:1 (2007), 23-47, has provided thorough criticism of Short's position. However, if we put together Short's and Dalton's arguments, 1141 would seem to be the moment at which no piece of evidence contradicts another.

27 On the provenance, see Crick, $S C$, p. 5o, and the marginalia in the manuscript, on fol. 43 r. The hand of the marginalia seems rather early, using for instance $e$-caudata.

28 Walter founded Kirkham Priory in 1130. See D. Knowles, The Monastic Order in England, 2nd ed., Cambridge, 1963, p. 229.

29 The main hand of the manuscript seems to date from around the middle of the 12th century, and a dating to the early 1140 s is within possible limits. However, another, laterlooking hand (using for instance crossed et nota) copied the lower half of the first page (and only that), in an ink of different hue. For the manuscript to date from Gaimar's time, the later-looking hand's work would need to be a significantly later addition, which cannot be proved. Certainly, however, the later-looking scribe wrote after the initials had been painted (ink overlaps the decoration), which is not the normal order of work and suggests some unusual history of production. 


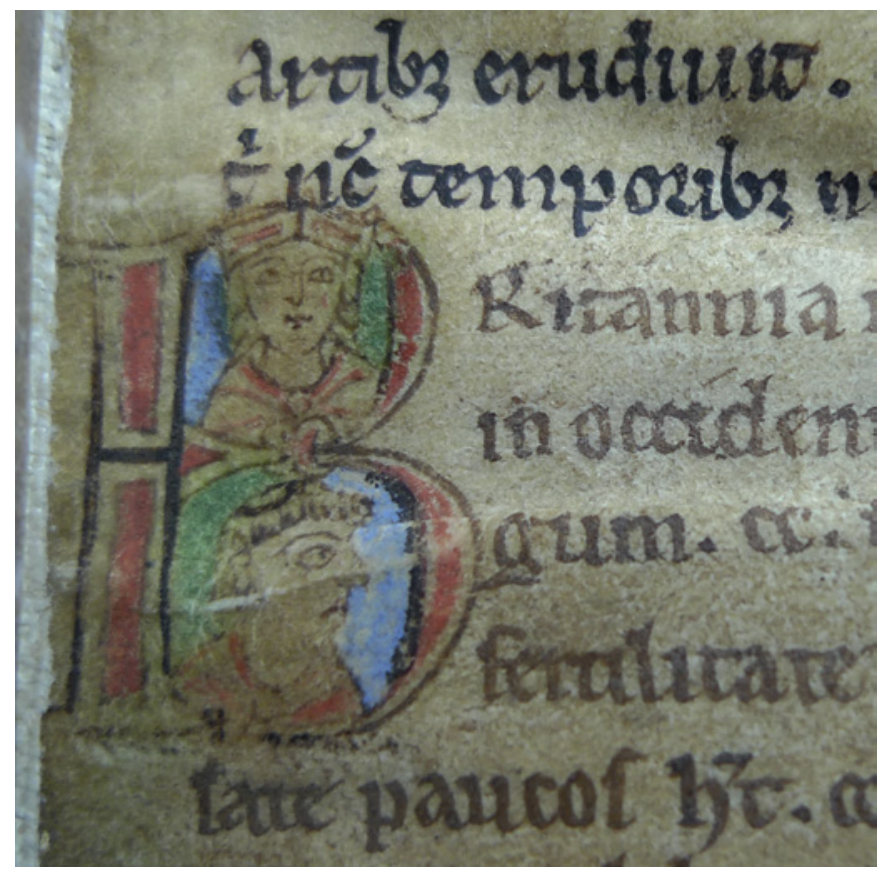

FIGURE 5.1 Cambridge, Gonville and Caius College, 406/627, fol. 1r

Altogether, there are nine British manuscripts which are related to Gonville and Caius $406 / 627 \cdot{ }^{30}$ Information on early provenance is unfortunately missing for most of them. However, we know that the copy textually closest to Gonville and Caius 406/627 was in Nun Appleton, just outside of York, in the 17th century, where it belonged to the small Fairfax family library, a locally sourced collection. ${ }^{31}$ Moreover, it is certain that Alfred of Beverley used a manuscript textually close to Gonville and Caius 406/627 in Yorkshire, c.1143, as he created his epitome of the $D G B \cdot{ }^{32}$ All the available evidence thus clusters close to Helmsley Castle (24 miles from York) where Walter Espec kept his copy of

30 Aberystwyth, National Library of Wales, Peniarth 42 (DGB ms 8), Porkington 17 (DGB ms 10); Cambridge, Gonville and Caius College, 103/55 (DGB ms 28); London, British Library, Harley 225 ( $D G B$ ms 10o); London, Lambeth Palace Library, 188 (DGB ms 199), 454, fols. 124r-204r ( $D G B$ ms 123); Oxford, Bodleian Library, Fairfax 28 (DGB ms 141), Rawlinson B. 148 ( $D G B$ ms 153); Philadelphia, The Free Library, E.247 (DGB ms 192).

31 For the Fairfax manuscripts, see F. Madan, H.H.E. Craster, and N. Denholm-Young, $A$ Summary Catalogue of Western Manuscripts in the Bodleian Library at Oxford, vol. 2, part 2, Oxford, 1937, pp. 772-89.

32 Reeve, "Introduction", p. xiv. 
the $D G B$, and it appears highly likely that Robert of Gloucester's book loan to him was indeed behind this textual group.

Manuscripts of the $\Phi$ family - the continental mainstream - also provided the textual starting point of two deliberately revised versions of the text, the so-called First and Second Variants, which were both created in Britain. We may assume that their makers also gained access to the text via Robert of Gloucester or circles close to him. Besides abbreviating the work to some extent, the First Variant recasts the whole text stylistically - it is the $D G B$ written in someone else's Latin. ${ }^{33}$ The First Variant was known to Wace at around 1150, but the earliest surviving manuscript dates from c.1200, and most are later, with Welsh associations. The Second Variant does not depart from the standard (so-called vulgate) version before about the middle of the work, but from then on it starts to abbreviate the text and does so increasingly as we approach its end. Unlike the First Variant, the Second Variant exists in numerous 12thcentury copies. The earliest of them, Cambridge, University Library, Mm.5.29 ( $D G B$ ms 54 ) is paleographically one of the most conservative of all British copies and may date from Geoffrey's lifetime. While the text of this manuscript represents the Second Variant only for its first half, its early date shows that the Second Variant came to be early in the transmission history of the $D G B .{ }^{34}$

Given the early date of the Variants, one wonders whether haste in copying was a factor contributing to their creation. The work became successful quickly and the few existing copies must have been in high demand in the early stages of the transmission. Besides appearing a likelihood, this is indeed suggested by the story of $\mathrm{G}$, post- $\mathrm{G}$, and their descendants examined above. Limited availability combined with high demand could easily have led into situations where an exemplar was available only for a short period. Several early manuscripts show traces of hurried copying. Two of them are among the most important textual witnesses of the other main textual family, the Insular $\Delta$. Cambridge, University Library, Dd.6.12 ( $D G B$ ms 43), in which the text of the $D G B$ occupies 115 folios, was copied neatly by one scribe until fol. 42 , but from then on anomalies of quire structure suggest that three scribes worked on the following parts simultaneously. ${ }^{35}$ In the last quire, as many as four different scribes participated into the copying and at this stage the aesthetic quality

33 For what can be known about its origins, see Wright, "Introduction", pp. lxx-lxxviii.

34 The scribe switched exemplars to a manuscript of another textual family around the point in which the omissions of the original text become substantial. See $D G B$, pp. xv and xxiii.

35 The second scribe, who copied the text until the beginning of the $P M$, needed an additional slip to finish his or her stint, inserted between fols. 60 and 61. The third scribe's stint ends mid-page, on fol. $67 \mathrm{v}$. 
of the handwriting deteriorates, probably because of extreme haste. Another copy, Oxford, Bodleian Library, Bodley 514 (DGB ms 136), shows probably six different hands, some of which use documentary-style-influenced scripts and write only short stints, which again gives the impression of copying being pushed through within an uncomfortably short span of time by recruiting all possible help. On the Continent, an early manuscript, now in the Palatine collection of the Vatican Library, was copied at least in part simultaneously, as is again indicated by anomalies in quire structure. ${ }^{36}$

Furthermore, poor exemplar availability probably contributed to how a manuscript with a very conspicuous mistake became widely used as an exemplar early on in the continental transmission. In 13 out of the 35 12th-century $\Phi$ family continental manuscripts, the name of the dedicatee, Robert of Gloucester, is missing. ${ }^{37}$ While dedications could be purposefully suppressed, this does not appear to have been what happened, since most of the dedicatory passage, containing other references to the patron, was left intact. The omission only managed to make the passage textually nonsensical, as is evinced by the various scribal emendations witnessed in most of its several descendants. ${ }^{38}$ Certainly, this omission happened very early, since many of the earliest continental manuscripts show it and it is unlikely that an exemplar with such a glaring shortcoming at the very beginning of the text would have been used if the text was already widely available. It has been suggested that the omission was originally a result of leaving the place for the name of the dedicatee empty for later completion in another color. ${ }^{39}$ For instance, Robert of Gloucester's halfsister, Empress Matilda, had a copy of Eckehardt of Aura's chronicle in which her name was inscribed in gold letters, and in which such a procedure of production must have been followed. ${ }^{40}$ One wonders whether the starting point of the nameless dedication transmission could have been a luxury copy which Robert commissioned in Normandy in late 1137 or 1138, but which remained on

$36 \quad$ Vatican City, Biblioteca Apostolica Vaticana, Pal. lat. 956 (DGB ms 195).

37 Aberystwyth, National Library of Wales, 11611 ( $D G B$ ms 2); Auxerre, Bibliothèque municipale, 91 ( $D G B$ ms 14); Brussels, Bibliothèque royale, 9871-9874 (DGB ms 20); Cambridge, University Library, Mm.1.34 ( $D G B$ ms 53); Madrid, Biblioteca Nacional de España, 6319 (F.147) ( $D G B$ ms 125); Montpellier, Bibliothèque interuniversitaire, 92 (DGB ms 126); Paris, Bibliothèque nationale de France, lat. 5233 ( $D G B \mathrm{~ms} 166$ ), lat. 6041B ( $D G B \mathrm{~ms} 173$ ), lat. 6231 ( $D G B$ ms 176), lat. 8501A ( $D G B$ ms 183), lat. 18271 ( $D G B$ ms 189); and Troyes, Médiathèque, 273bis ( $D G B$ ms 208).

38 On the "nameless dedication", see Reeve, “Transmission", p. 81 (esp. n. 19) and Crick, $D R$, p. 118, n. 38 .

39 See Reeve, "Transmission", p. 81, n. 20. As both Crick and Reeve explain, the original idea was presented by Mary Garrison.

40 Cambridge, Corpus Christi College, 373, fol. 95v. 
the Continent in an incomplete state when he left Normandy for England in September 1139 .

Robert of Gloucester's active role in the early circulation of the $D G B$ is suggested by Gaimar's testimony, the characteristics of the textual tradition depending on $\Phi$ and, more tentatively, by the nature of the nameless dedication. It is as well a possibility that he was involved in the two other dedications with which the $D G B$ is found. The first of these addresses Robert together with Waleran, Count of Meulan, and the second Robert together with King Stephen.

These double dedications have been much debated because Waleran and Stephen were Robert's enemies in the civil war of Stephen's reign. The conflict went back to Henry I's disputed succession. After Henry had died without a male heir, Stephen, Count of Boulougne and grandson of William the Conqueror, swiftly took the English throne which Henry had promised to his daughter, Matilda. Waleran of Meulan's support was essential for Stephen's consolidation of his position. Robert, on the other hand, was Matilda's halfbrother and closest ally, and he eventually took up her cause and started a war against Stephen in 1139. Acton Griscom, who discovered the double dedication, considered it to have been the original one, penned before relations between Robert and Waleran became openly hostile, and this idea has had some support until recently. ${ }^{41}$ Reeve's work on the textual history has however proved what others have long suspected on the account of internal evidence, namely, that the first dedication was to Robert alone. ${ }^{42}$

One must ask why Geoffrey re-dedicated a work, already presented to Robert, jointly to him and his enemies. Gaimar's testimony and the textual history suggest that the presentation to Robert was actually working in favor of the $D G B$ 's circulation. Re-dedication to a bitter rival could have risked good relations with this useful literary promotor, if this action was initiated by the author alone. At the same time, Alfred of Beverley's famous testimony from the early 1140s shows that Geoffrey's work was quickly turning out to be a bestseller,

41 See Geoffrey of Monmouth, De gestis Britonum, ed. A. Griscom, The Historia Regum Britanniae of Geoffrey of Monmouth with Contributions to the Study of its Place in early British History with a Literal Translation of the Welsh Manuscript No. LXI of Jesus College Oxford, London, 1929, pp. 42-98. See as well D. Dumville, "An Early Text of Geoffrey of Monmouth's Historia regum Britanniae and the Circulation of some Latin Histories in Twelfth-Century Normandy", $A L 4$ (1985), 1-36, at p. 27; D. Crouch, "Robert, earl of Gloucester", p. 23o; Short, “Gaimar's epilogue”, pp. 338-39; M. Aurell, La légende du Roi Arthur: 550-1250, Paris, 2007, p. 102.

42 Elsewhere in the text (also in the double dedication version) Geoffrey refers to his patron in the singular: consul auguste, "most noble earl" ( $D G B$, xi.177.1). For example, see Tatlock, $L H B$, p. 436 . On the implications of the textual history for the chronology of the dedications, see $D G B$, pp. ix-X, esp. p. xix. 
something fashionable people needed to be acquainted with. ${ }^{43}$ Presenting tailored copies of the $D G B$ to other men of power, with Robert kept in as the original patron of the work, could have been Robert's way of asserting his status. As we shall see, neither Waleran or King Stephen at least in any way contributed to the distribution of the $D G B$, while Robert certainly did so. This suggests they may have been less than enthusiastic about the books they received.

The first and by far the more popular of the double dedications was the one addressing Robert jointly with Waleran. Considering the possibility that it was made with Robert's participation, appropriate circumstances would have occurred in the summer of 1141 when Waleran left England and made his peace with Robert. At this point, the two magnates met, witnessing charters by which Bordesley Abbey passed from Waleran to Matilda as part of the process of reconciliation. ${ }^{44}$ The charters were written at Devizes, but throughout the period Robert and Matilda's court was based at Oxford, Geoffrey of Monmouth's probable place of residence. The Insular origin of the double dedication is supported by the fact that it is found in eight Insular but only two continental 12th-century manuscripts (including manuscripts dated to $s$. xii/ xiii), in both of which the double dedication has, furthermore, been added to a text originally dedicated to Robert alone. ${ }^{45}$ This textual situation - the double dedication receiving relatively wide circulation in Britain but almost none on

43 Alfred of Beverley, Annals, ed. T. Hearne, Aluredi Beverlacensis Annales, sive historia de gestis regum Britanniae, libris IX. E codice pervetusto ..., Oxford, 1716, p. 2: "Ferebantur tunc temporis per ora multorum narraciones de hystoria Britonum, notamque rusticitatis incurrebat, qui talium narracionum scienciam non habebat ... Quid plura? Quaesivi hystoriam, \& ea vix inventa, leccioni ejus intentissime studium adhibui", "At that time many people were telling stories about the history of the Britons and it was a sign of boorishness not to be acquainted with these ... What else? I looked for the history and, once I had found it, I dedicated myself to reading it."

44 Regesta regum Anglo-Normannorum, ed. Davis et al., vol. 3, nos. 115 and 116, dated to ${ }_{25}$ July-15 September, but in fact predating 12 August. See D. Crouch, The Reign of King Stephen 1135-1154, New York, 2000, pp. 183-84, n. 41, and M. Chibnall, The Empress Matilda: Queen Consort, Queen Mother and Lady of the English, Oxford and Cambridge, MA, 1991, pp. 134-35. Acton Griscom was aware of the above documents and discussed the possibility of the joint dedication having been made for the occasion, but he dismissed this theory, largely because he was misinformed about the chronology of the dedications (he considered the joint dedication the original one, a theory now discredited). See Geoffrey of Monmouth, De gestis Britonum, ed. Griscom, pp. 69-8o.

45 Cambridge, Trinity College, O.2.21 ( $D G B \mathrm{~ms}$ 39, Insular); Cambridge, University Library, Ii.1.14 ( $D G B$ ms 48, Insular), Ii.4.4. ( $D G B$ ms 49, Insular); London, British Library, Lansdowne 732 ( $D G B \mathrm{~ms} \mathrm{107}$, Insular); New Haven, Beinecke Library, 590 ( $D G B$ ms 128, Insular); Oxford, Bodleian Library, Additional A.61 ( $D G B$ ms 134, Insular), Bodley 514 ( $D G B$ ms 136, Insular); Paris, Bibliothèque nationale de France, lat. 6040 ( $D G B \mathrm{~ms} \mathrm{170}$, probably Insular); Vatican City, Biblioteca Apostolica Vaticana, Reg. lat. 692 (DGB ms 197, continental; joint 
the Continent - suggests that Waleran did not promote the version dedicated to him in any measure. He, after all, left England at the end of the summer of 1141, never to return. Consequently, the source for the dissemination of the double dedication in Britain cannot have been the copy he received.

As it happens, we can locate the precise exemplar from which the (completely Insular) transmission of the double dedication text started. Textually, all the manuscripts with the joint dedication to Robert and Waleran are similar. They represent the Insular $\Delta$ branch of transmission, except for one passage ( $\S 114-37)$ in which they follow $\Phi$, i.e., the other archetype and the probable presentation copy whose descendants dominate the continental tradition. We can be certain that they all descend from Paris, Bibliothèque nationale de France, lat. 6040, of Insular origin, which provides a material answer to this textual puzzle. In Paris 6040, the chapters in which the text follows $\Phi$ (§§114-37) form a single quire (fols. $\left.33^{-}{ }^{-} 39 \mathrm{v}\right)$, copied by a hand that is different from but contemporary with the main hand. On the final verso side of this quire (fol. 39v), we can, furthermore, see the scribe stretching his letters and spacing them more widely so as to fit the text neatly on the remaining side. In other words, it appears that the whole text of Paris 6040 was originally copied from an exemplar with the $\Delta$ type text, but that one quire was soon lost and the missing part of the text was resupplied from a different source.

Indeed, there is material evidence that the manuscript went through an accident, most likely as it was being bound. All of the folios in Paris 6040, except those of the quire copied by the different scribe, soon after their writing lost a triangular piece of parchment from their inner top corner, as if a blade had cut through the whole book, and this is no doubt what actually happened (it is difficult to imagine any other instrument than binder's guillotine causing such neat damage). Every single folio was immediately repaired by carefully gluing a patch of parchment on each bifolium, and the lost text was recopied on these patches, apparently by the original scribe. It appears likely that it was in this process of repair - we must imagine a room full of bifoliums under weights being glued - that one quire went missing. Reeve's conclusion is that $\Delta$ and $\Phi$ were both authorial versions of the text, and that $\Delta$ was probably the later of these, produced presumably by authorial revision of the draft. ${ }^{46}$ Considering the possibility that Robert of Gloucester was involved in the making of the double dedication, it is at least a curious coincidence that the manuscript from which all the double dedication copies descend brought together the text as

dedication added in the margin but later erased), and Vat. lat. 2005 (DGB ms 199, continental; follows the double dedication version only for the first chapters). 
it had been presented to Robert $(\Phi)$ and the authorially revised version $(\Delta)$, which was probably in Geoffrey's possession.

A text of the same hybrid type, always descending from Paris 6040, accompanied the second re-dedication, jointly to Robert and King Stephen. This was, however, produced with less effort. It is a lazy reworking of the dedication to Robert and Waleran, created by altering the names and titles so that Robert became Stephen and Waleran became Robert. The text which accompanies it is furthermore quite corrupt, so presumably this second joint dedication came about with an ad hoc modification hastily made to a manuscript with the double dedication to Robert and Waleran that happened to be available, not as a deliberately produced presentation copy. A possible context for its making would have been provided the curious circumstances of September to October 1141. At this point, Robert and King Stephen had both been taken prisoner by the opposing side and negotiations over their exchange were taking place.

\section{Monastic Manuscripts}

Individual bibliophiles, whether monks like Robert of Torigni, secular ecclesiastics such as Alexander of Lincoln, or lay magnates such as Robert of Gloucester and Walter Espec, played a significant role in the dissemination of the $D G B$. However, despite its secular tone and the evidence for the activity of individual readers in its circulation, monastic libraries were at least as important for the early transmission, especially on the Continent.

We have seen how the $D G B$ was incorporated into an already existing codex containing serious historical texts at Le Bec around 1150, and compilations of this kind became the main vehicle of its transmission in institutional contexts. Over the third quarter of the century, we can identify historical compilations containing the $D G B$ made at the Cistercian house of Pontigny (Burgundy, c.1164-66), ${ }^{47}$ Saint-Germain-des-Prés (Paris, in or soon after 1168$),{ }^{48}$ the

47 Montpellier 92 (DGB ms 126). On the content, see Crick, $S C$, pp. 208-og; on the origin, see M. Peyrafort-Huin, La bibliothèque médiévale de l'Abbaye de Pontigny (XII ${ }^{e}-X I X^{e}$ siècles), Paris, 2001, pp. 64-65 and 541-42.

48 Paris, Bibliothèque nationale de France, lat. 12943 ( $D G B$ ms 184). See Crick, $S C$, pp. 286-88 and J. Tahkokallio, "Monks, Clerks and King Arthur: Reading Geoffrey of Monmouth in the Twelfth and Thirteenth Centuries", unpublished PhD dissertation, University of Helsinki, 2013, pp. 190-91. 
Benedictine abbey of Anchin (Flanders) ${ }^{49}$ and an unidentified monastic scriptorium in Reims..$^{50}$ At Pontigny, the $D G B$ was copied in tandem with Bede's Ecclesiastical History, while at Saint-Germain-des-Prés, the $D G B$ was joined to an earlier, 11th-century copy of the same work. At Anchin, it was accompanied by Dudo of Saint-Quentin's The Customs and Deeds of the First Dukes of the Normans and in Reims by Ademar of Chabannes's Chronicle. From the last quarter of the 12th century we find manuscripts of similar content from the Benedictine houses of Marchiennes (Flanders), ${ }^{51}$ Fécamp (Normandy), ${ }^{52}$ and Saint Evroul (Normandy), ${ }^{53}$ and the Cistercian abbeys of Chaalis (Picardy) ${ }^{54}$ and Valuisant (Burgundy). ${ }^{55}$ Early in the 13th century, further compilations were produced at Jumièges (Benedictine, Normandy), ${ }^{56}$ St Martin (Benedictine, Tournai), ${ }^{57}$ and, slightly later, Aurillac (Benedictine, Auvergne) ${ }^{58}$ By this time, the $D G B$ was transmitted in monastic compilations in German-speaking areas as well, copied at Salem (Cistercian, Konstanz), ${ }^{59}$

49 Douai, Bibliothèque municipale, 88o ( $D G B$ ms 59). See Crick, $S C$, pp. 93-94 and Tahkokallio, "Monks, Clerks and King Arthur", pp. 169-70.

50 Paris, Bibliothèque nationale de France, lat. $6041 \mathrm{~B}$ ( $D G B$ ms 173). On the content, see Crick, $S C$, p. 273; on the origin, see P. Bourgain, "Un nouveau manuscrit du text tronqué de la Chronique d'Adhemar de Chabannes", Bibliothèque de l'École des chartes 143 (1985), 153-59, esp. p. 155 .

51 Douai, Bibliothèque municipale, 882 (838) (DGB ms 6o). On the content and origin, see Crick, SC, pp. 94-98 and Tahkokallio, "Monks, Clerks and King Arthur", p. 170.

52 Bern, Burgerbibliothek, 568 ( $D G B$ ms 15 ). On the content and origin, see Crick, $S C$, pp. 21-25 and Wright, "Introduction", pp. xxxv-xliii.

53 Alençon, Bibliothèque municipale, 12 ( $D G B$ ms 12). On the content, see Crick, $S C$, pp. 15-17; on the origin, see G. Nortier, "Les Bibliothèques médiévales des abbayes bénédictines de Normandie. IV. La bibliothèque de Saint-Evroul", Revue Mabillon 47 (1957), 219-44, at p. 220.

54 Paris, Bibliothèque nationale de France, lat. 17569 ( $D G B$ ms 188). On the content and origin, see Crick, SC, pp. 292-93 and Tahkokallio, "Monks, Clerks and King Arthur", p. 191.

55 Auxerre, Bibliothèque municipale, 91 (85) ( $D G B$ ms 14). On the content and origin, see Crick, $S C$, pp. 19-21 and F. Bougard, P. Petitmengin, \& P. Stirnemann, La bibliothèque de l'abbaye cistercienne de Vauluisant, Paris, 2012, pp. 34, 36, 159-61.

56 Rouen, Bibliothèque municipale, U.74 (1177) ( $D G B$ ms 200). On the content and origin, see Crick, SC, pp. 305-06 and Tahkokallio, "Monks, Clerks and King Arthur", p. 194.

57 Brussels, Bibliothèque royale, II.1O2o ( $D G B$ ms 21). On the content and origin, see Crick, SC, pp. 32-33 and A. Boutemy, "Note sur l'origine et la date du Status Imperii Iudaici", Scriptorium 1 (1946/47), 66-69, at p. 66.

$5^{8}$ Montpellier, Bibliothèque interuniversitaire, $\mathrm{H}_{142}$ ( $D G B \mathrm{~ms} 222$ ). On the content and origin, see Tahkokallio, "Update", pp. 196-99.

59 Heidelberg, Universitätbibliothek, 9.31 (DGB ms 75). On the content, see Crick, SC, pp. 12224; on the origin see W. Werner, Die mittelalterlichen nichtliturgischen Handschriften des Zisterzienserklosters Salem, Wiesbaden, 200o, p. 231. 
Allerheiligen (Benedictine, Schaffhausen), ${ }^{60}$ and probably at Heisterbach (Cistercian, Nordrhein-Westfalen). ${ }^{61}$ This kind of transmission suggests that the $D G B$ was taken seriously and seen as a worthy addition to the body of historical information that these religious houses possessed.

In Britain, early institutional readership was more restricted, to judge by the surviving manuscripts. To appreciate the differences, one must keep in mind that over the first century of the $D G B$ 's dissemination - before $c .1250$ the overall numbers of copies attributable to the Continent and to Britain are similar. Excluding the non-localizable manuscripts, ${ }^{62}$ there are 49 probably continental and 45 probably Insular copies. However, while 16 of these continental manuscripts have a probable institutional origin, a monastic origin has been suggested for just three Insular manuscripts (Battle, Margam, and St Albans). ${ }^{63}$ This paucity of Insular institutional copies does not result from any general lack of monastic historical manuscripts, which is well demonstrated by a simple comparison with William of Malmesbury's Deeds of the English Kings. From before $c .125$, the Deeds of the English Kings survives in 16 probably British copies ${ }^{64}$ - as compared to the approximately 45 British copies of the $D G B$ from the same period. However, nine copies of the Deeds of the English Kings (against three of the $D G B$ ) have a proposed institutional origin. Manuscripts of William's work were probably copied at the Benedictine

6o Schaffhausen, Stadtbibliothek, Min. 74 ( $D G B$ ms 218). On the content and origin, see Tahkokallio, "Update”, pp. 188-91 and R. Gamper, G. Knoch-Mund, \& M. Stähli, Katalog der mittelalterlichen Handschriften der Ministerialbibliothek Schaffhausen, Dietikon-Zürich, 1994, p. 35 .

61 London, British Library, Harley 3773 ( $D G B$ ms 102). On the content and area of origin, see Crick, $S C$, pp. 166-68. My interpretation of its precise origin is based on the presence of several texts attributed to Cesarius of Heisterbach, including what seem drafts for his version of the Catalogus episcoporum Coloniensium. A full analysis of the manuscript awaits publication.

62 Cambridge, Trinity College, R.7.6 (DGB ms 36); Oxford, All Souls College, 35 ( $D G B$ ms 132); and Paris, Bibliothèque nationale de France, lat. 6232 ( $D G B$ ms 177).

63 Battle (Benedictine, Sussex, s. xii ${ }^{2}$ ): London, British Library, Royal 4 C. xi (DGB ms 108); Margam (Cistercian, Glamorgan, s. xii/xiii): London, British Library, Royal 13 D. ii ( $D G B$ ms 112); St Albans (Benedictine, Hertfordshire, s. xiii' ${ }^{1}$ ): London, British Library, Royal 13 D. v (DGB ms 113).

64 Cambridge, Trinity College, R.7.10 and R.7.1; Cambridge, University Library, Ii.2.3; London, British Library, Arundel 35, Harley 261, Cotton Claudius C. ix, Additional 23147, Harley 447, Royal 13 D. v, and Royal 13 D. ii; Oxford, All Souls College, 33, 35, and b. 32, no. 22; Oxford, Bodleian Library, Laud Misc. 548 and Laud Misc. 729. 
centers of Bury, ${ }^{65}$ Rochester, ${ }^{66}$ Battle, ${ }^{67}$ Llanthony, and St Swithun (Winchester), ${ }^{68}$ at the Cistercian abbeys of Buildwas, ${ }^{69}$ Margam, ${ }^{70}$ and Merevale, ${ }^{71}$ and at the Augustinian house of Newark (Surrey). ${ }^{72}$ It is remarkable that a work with a clearly more restricted overall diffusion penetrated institutional collections in Britain so much more efficiently.

Compared to the Continent, the British manuscripts of the $D G B$ also more often contain only this work. Before $c .1250,25$ of the continental manuscripts of the $D G B$ are compilations, but this is the case with just 13 Insular ones. Since there is a strong correlation between monastic origin and compilation format on the Continent, this difference in codicology could well be taken to suggest more limited institutional circulation in Britain. ${ }^{73}$

The situation, however, changed over the second half of the 13th century. Between $c .1250$ and the beginning of the 14th century (including manuscripts dated to $s$. xiii/xiv), as many as 14 compilations containing the $D G B$ produced in Britain survive, ${ }^{74}$ and five of these have a probable monastic ori-

65 London, British Library, Harley 447. On the origin, see W. Stubbs, "Preface", in id. (ed.), Willelmi Malmesbiriensis monachi De gestis regum Anglorum libri quinque, 2 vols., London, 1887-89, vol. 1, pp. ix-cxlvii, at p. lxxvii; N. Ker, Medieval Libraries of Great Britain: A List of Surviving Books, London, 1964, p. 20.

66 London, British Library, Harley 261. On the early Rochester connection, see Stubbs, "Preface", p. lxxiv and Ker, Medieval Libraries, p. 161.

67 BL Cotton Claudius C. ix. On the origin, see Stubbs, "Preface", pp. lxxxiii-iv.

68 BL Arundel 35. On the origin, see Stubbs, "Preface", p. lxvii, and Thomson and Winterbottom, "Introduction", p. xv.

69 CUL Ii.2.3. On the origin, see P. Binski \& P. Zutshi, Western Illuminated Manuscripts: A Catalogue of the Collection in Cambridge University Library, Cambridge, 2011, pp. 59-6o.

$70 \quad$ BL Royal ${ }_{13}$ D. ii. On the origin, see Crick, $S C$ and King, "Introduction", pp. xci-xciv.

71 Oxford, All Souls College, 33. On early provenance, see A. Watson, Descriptive Catalogue of the Medieval Manuscripts of All Souls College, Oxford, Oxford, 1997, p. 66. Use of flex punctuation and overall appearance suggest Cistercian origin as well; see M. Parkes, Pause and Effect: An Introduction to the History of Punctuation in the West, Berkeley, 1993, pp. 39-40.

72 Oxford, Bodleian Library, Laud Misc. 548 (1377). On the origin, see Stubbs, "Preface", pp. lxviii-lxix. There is some overlap, since two of the manuscripts contain both Geoffrey and William (BL Royal 13 D. ii and Royal 13 D. v).

73 There are 25 continental compilations from before $c .125$, 14 of which have a probable institutional origin.

74 Aberystwyth, National Library of Wales, 13210 ( $D G B$ ms 4), Llanstephan 176 (DGB ms 6); Cambridge, Clare College, 27 ( $D G B$ ms 22); Cambridge, Trinity College, O.2.21 ( $D G B$ ms 39); Cambridge, University Library, Dd.10.31 ( $D G B$ ms 44); Dublin, Trinity College, 515 (E.5.12) ( $D G B$ ms 67); Exeter, Cathedral Library, 3514 ( $D G B$ ms 70); London, British Library, Arundel 326 ( $D G B \mathrm{~ms} 88$ ), Cotton Vespasian E. x ( $D G B \mathrm{~ms} 98)$, Egerton 3142 (DGB ms 99), and Harley 4003 (DGB ms 103); Oxford, Bodleian Library, Laud Misc. 720 (DGB ms 150); Oxford, Christ Church, 99 ( $D G B$ ms 16o); Paris, Bibliothèque nationale de France, lat. 4999A; and Manchester, John Rylands Library, lat. 216 (DGB ms 165). 
gin: Robertsbridge (Cistercian, Sussex), ${ }^{75}$ St Albans, ${ }^{76}$ Whitland (Cistercian, Wales), ${ }^{77}$ Abingdon (Benedictine, Oxfordshire), ${ }^{78}$ and Holme (Benedictine, Norfolk). ${ }^{79}$ The slower take-off of monastic dissemination may indicate that British audiences were more critical of the truth value of the work than continental ones. This does not seem surprising, given that the English church traced its roots back to the late sixth-century Gregorian mission and that Bede's work was the canonical account of its origins. A text that told about late Roman and early medieval Christian society and conflicted with Bede in its details could easily have met with some resistance. Whereas the $D G B$ was quickly accepted as an uncontroversial addition to the corpus of historical information in France and Flanders, it was only over the 13th century that Galfridian facts became historical mainstream in Britain, concurrently with the rise of the Latin and vernacular Brut traditions.

\section{3} Books for Individuals?

In all these institutional manuscripts, the text of Geoffrey's $D G B$ comprises part of a compilation containing other historical texts. However, most manuscripts of the $D G B$ are not compilations at all. If we look at all the non-fragmentary copies from before $c .1300$, we see that 66 out of 126 ( $5^{2}$ per cent) are single-text manuscripts, containing only the $D G B$. These single-text copies and the compilations contrast starkly in terms of how much is known about their origins. Whereas 23 of the compilations have been attributed with a probable institutional origin, we do not know the precise origin of any of the single-text manuscripts. There is also a clear difference in format. The single-text copies are less bulky, having an average page area of $359 \mathrm{~cm}^{2}$ as opposed to the $568 \mathrm{~cm}^{2}$ of the compilations.

The contrast in origin information suggests that a much smaller proportion of the single-text copies were actually produced for institutional collections.

75 NLW 13210 (DGB ms 4). On the content and origin, see Crick, $S C$, p. 7.

76 Cambridge, Clare College, 27 ( $D G B$ ms 22). On the content and origin, see Crick, $S C$, pp. 33-34 and N. Morgan, "Matthew Paris, St Albans, London, and the leaves of the 'Life of St Thomas Becket', Burlington Magazine 130 (1988), 85-96, at p. 9o, n. 22, and p. 92.

77 Exeter 3514 ( $D G B$ ms 70). On the origin and content, see Crick, $S C$, pp. 114-17 and ead., "The Power and the Glory: Conquest and Cosmology in Edwardian Wales (Exeter, Cathedral Library 3514)", in O. Da Rold and E. Treharne (eds.), Textual Cultures: Cultural Texts, Cambridge, 2010, pp. 21-42, at pp. $30-34$.

78 BL Arundel 326 ( $D G B$ ms 88). On the origin and content, see Crick, $S C$, pp. $142-44$ and Ker, Medieval Libraries, p. 2.

79 BL Egerton 3142 (DGB ms 99). On the origin and content, see Crick, SC, pp. 163-64. 
The same idea is conveyed by the difference in size, the monastic library books often (if by no means always) being of relatively large format. My suspicion is that many of the single-text copies were produced for individual owners. The writing of the $D G B$ coincided with a great expansion in both the supply and demand of writing, a key feature of the so-called 12th-century renaissance. Cathedral schools were churning out a new educated class, which found employment in royal, episcopal, and comital chapels and chanceries, and sometimes possibly also in lesser aristocratic households. The incipient commercialization of book production was one feature of this new dynamism, both making it easier (for wealthy secular clerks) to commission books and offering opportunities for scribal employment (for their less well-off colleagues). When considered quantitatively, the codicology of the copies of the $D G B$, put together with information about their origins, appears to reflect these developments.

A manuscript's origin as a book produced for personal use is difficult to prove, however. Not one of the 12th- or early 13 th-century century copies of the $D G B$ bears a contemporary ex libris inscription indicating private ownership. We are thus left with paleographical, or, more broadly, typological and material criteria for identifying such books, and these are not very helpful at this point in time. In the 13th century, it is possible to recognize books produced on commission by urban craftsmen, often for individuals, on stylistic criteria. Book production had by then become an organized commercial craft, and this development was accompanied by the creation of relatively fixed styles of decoration and layout, at least in the most important centers of production. ${ }^{80}$ The 12th-century situation was, however, different. While manuscripts were

8o On the emergence of such styles, see e.g. F. Avril, "A quand remontent les premiers ateliers d'enlumineurs laïcs à Paris", Les Dossiers de l'archéologie 16 (1976), 36-44; B. Brenner, Manuscript Painting in Paris during the Reign of Saint Louis: a Study of Styles, Berkeley, 1977; P. Stirnemann, Quelques bibliothèques princières et la production hors scriptorium au $X I I^{e}$ siècle, Paris, 1984; ead., "Fils de la vierge. L'initiale à filigranes parisiennes: 1140-1340", Revue de l'Art 90 (1991), 58-73. On early "commercial" book production generally, see, e.g., C. De Hamel, Glossed Books of the Bible and the Origins of the Paris Booktrade, Woodbridge, 1984; M. Rouse \& R. Rouse, Manuscripts and Their Makers: Commercial Book Producers in Medieval Paris, 1200-1500, 2 vols., Turnhout, 2000; id., "The Book Trade at the University of Paris, ca. 1250-ca. 1350", in L. Bataillon, B. Guyot, and R. Rouse (eds.), La Production du livre universitaire au moyen âge, Paris, 1988, pp. 41-114; A. Stones, "Secular Manuscript Illumination in France", in C. Kleinhenz (ed.), Medieval Manuscripts and Textual Criticism, Chapel Hill, 1976, pp. 83-102; and P.M. de Winter, "Copistes, éditeurs et enlumineurs de la fin du XIV e siècle: la production à Paris de manuscrits à miniatures", in Actes du Congrès national des sociétés savantes: Section d'archéologie et d'histoire de l'art, Paris, 1978, pp. 173-98. 
certainly produced on commission then as well, the styles and arrangements by which they were made were more varied.

Nevertheless, over the century, styles of decoration developed which can be associated with emerging proto-commercial book production, and some manuscripts of the $D G B$ reflect them. The earliest of these is Vatican City, Biblioteca Apostolica Vaticana, Pal. lat. 956, datable to around or before the middle of the 12th century. ${ }^{81}$ This manuscript has pen decoration which echoes the style seen in books produced in Chartres in the 1130s and 1140s, even though the initials are not "pure" representatives of this style. ${ }^{82}$ Still more informal and simplified versions of the Chartrain motifs of penwork can be seen in the initials of Paris, Bibliothèque nationale de France, lat. 6232 ( $D G B$ ms 177). In this manuscript, probably produced in the north of France, partly from an Insular exemplar, the penwork is in red, blue, and green, in contrast to the red-blue aesthetics of the proper Chartrain flourishes. The Chartres-style decoration is seen in many high-grade manuscripts known to have been produced on commission, and its emergence appears to be one reflection of the incipient professionalization of bookmaking. ${ }^{83}$ Its influence on the decoration of these less sumptuous and more quickly produced copies of the $D G B$ could indicate that these books, as well, were made in secular contexts, possibly for individual users.

In addition to the pen decoration, the Chartres-style books often have distinctive and very elaborate major initials which are not found in Pal. lat. 956 or BnF lat. 6232. This is not surprising, given the relatively modest quality of these books and the fact that the Palatine manuscript, the finer one, has lost its first quire, in which the only major illuminated initials of the $D G B$ are usually located. ${ }^{84}$ Another manuscript, however, may point indirectly at the existence of an early, high-grade copy with such major initials. This is Paris, Bibliothèque nationale de France, lat. 8501A ( $D G B$ ms 183). The manuscript itself is later, from the second half of the 12th century. It contains several texts copied by multiple hands and it is by no means luxurious. Most of its initials are simple, single-color letters, sometimes with modest pen flourishes, but the first two

$81 \quad$ BAV Pal. lat. 956 (DGB ms 195).

82 I owe this observation to Michael Gullick.

83 P. Stirnemann, "Où ont été fabriqués les livres de la glose ordinaire dans la première moitié du xiie siècle?", in F. Gasparri (ed.), Le xiie siècle: mutations et renouveau 1120-1150, Paris, 1994, pp. 257-85, at pp. $272-73$ and pl. x, and Stirnemann's pdf, <http://www.manuscrits -de-chartres.fr/sites/default/files/fileviewer/documents/reconnaitre-ms/decor-styles_ chartrains_petit_o.pdf> (accessed 5 October 2017).

84 Major initials are by far the most commonly seen in the beginning of the work, for example, the "C" of Cum mecum, $D G B$, Prologus 1.1) and the "B" of Britannia (DGB, Prologus $5.24)$. 


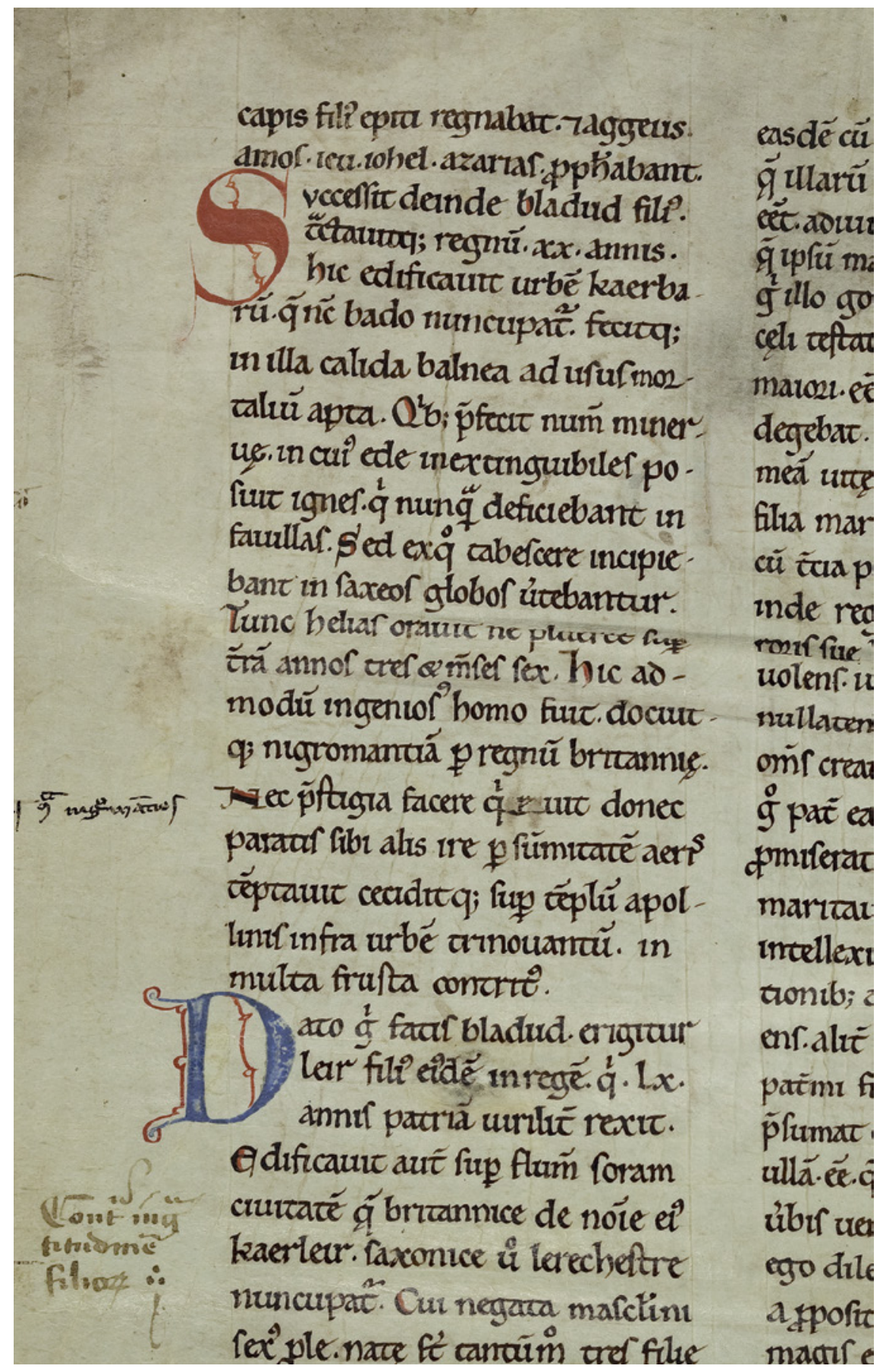

FIgure 5.2 Vatican City, Biblioteca Apostolica Vaticana, Pal. lat. 956, fol. iv 
at the beginning of the $D G B$ stand out from the rest. These are simply drawn by pen, but they are clearly imitations of elaborate multicolor initials, probably specifically of the type seen in many commissioned 12th-century books from the middle of the century. The large initial "B" beginning $§ 5$ of the $D G B$ in particular bears an uncanny resemblance to the elaborate initials produced by an artist active in Chartres in the 1140s, identified by Patricia Stirnemann. ${ }^{85}$ Looking at the rendering of the details, this letter appears to be a copy of something resembling the initial found in Tours, Bibliothèque municipale, 93, fol. $2 \mathrm{v}$ or Troyes, Bibliothèque municipale, 2391, fol. 34V, a book made for Thibaut II, Count of Champagne (1090-1152), whose son Henry (the Liberal, 1127-81), arguably owned a copy of the $D G B \cdot{ }^{86}$ The fact that the manuscript contains one of the two surviving copies of a rare text, A Poem on Muhammad (Otia de Machomete), known to have been written in Chartres between 1137 and 1155, supports connecting this manuscript with Chartres. ${ }^{87}$ It has been suggested that BnF lat. 8501A may have been copied at Mont-Saint-Michel, this association being based on the resemblance of a marginal drawing representing King Arthur (fol. $108 \mathrm{v}$ ) to the style of pen-drawn illustrations produced at Mont during Robert of Torigni's abbacy (1154-86). ${ }^{88}$ While some stylistic similarity can indeed be seen, this does not constitute proof of the manuscript's origin, especially since the marginal drawing could have been supplied later. ${ }^{89}$

In this chapter, I have but scratched the surface of the wealth of information that the manuscripts of the $D G B$ can provide. They not only inform us about the contemporary reception of Geoffrey's work but also open a window into a rare corner of 12th-century book culture. The large number of the manuscripts

85 See Stirnemann, "Où ont été fabriqués les livres", pp. 270-71.

86 See Stirnemann, Quelques bibliothèques princières, p. 22, and ead., "Les bibliothèques princières et privées aux XII ${ }^{\mathrm{e}}$ et XIII ${ }^{\mathrm{e}}$ siècles", in A. Vernet (ed.), Histoire des bibliothèques françaises, Tome 1. Les bibliothèques médiévales du VIe à 1530, [Paris], 1989, pp. 173-91, at p. 177 .

87 Robert Huygens, editor of the text, thought it probable that both surviving copies reflect the same exemplar, which was close to the authorial text. See R.B.C. Huygens, "Otia de Machomete [A poem on Muhammad], Gedicht von Walter von Compiegne", Sacris erudiri 8 (1956), 287-328.

88 M.-F. Damongeot-Bourdat, "Le roi Arthur et le Mont-Saint-Michel", Les Amis du MontSaint-Michel 115 (2010), 36-41, at p. 41. For the style of drawing, see M. Bourgeois-Lechartier \& F. Avril, Le Scriptorium du Mont Saint-Michel, Paris, 1967, esp. pp. 18-19 and p. 46, and figures 44,81 and $126-28$.

89 Since Robert of Torigni's handwriting has recently been identified (Pohl, "Abbas qui et scriptor?") it can be observed that his hand does not seem to appear in BnF lat. 8501A. This is of course no proof that the manuscript could not have been copied at or for Mont-Saint-Michel, but given the central role of Robert in the transmission of the $D G B$, this absence is worth noting. 

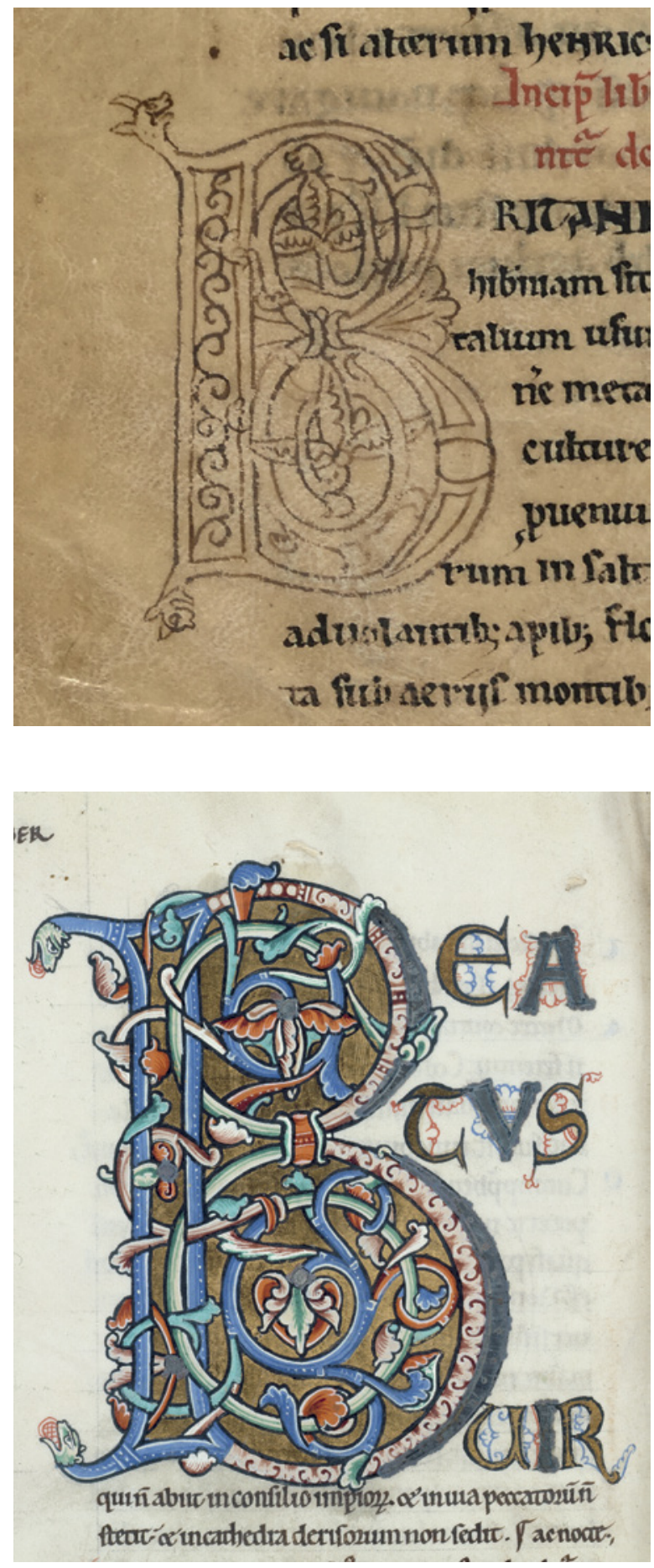

FIGURE 5.3

Paris, Bibliothèque nationale de France, lat. $8501 \mathrm{~A}$, fol. $63 \mathrm{v}$
FIGURE 5.4

Troyes, Bibliothèque municipale, 2391, fol. $34 \mathrm{~V}$ 
of the $D G B$ is remarkable since its copying cannot have been based on any kind of institutionalized demand or captive audience. Most medieval bestsellers were works which had a specific audience that could not do without them: canon law books were necessary for bishops and episcopal administrators, school books for scholars, and texts on monastic spirituality for monasteries. There were, however, no similarly binding reasons why anyone needed to own an arguably newly-translated ancient history. As a literary phenomenon, the $D G B$ came as close to what we mean by the word "bestseller" as it is possible to get in a medieval Latin context: it was a work whose success was based on the appeal that the text had to its readers. As such, its manuscripts tell us about the various ways in which books were produced and procured in the 12th century: monastic copying, professional book production, and various kinds of ad hoc arrangements. Much paleographical and codicological work remains to be done on them. 